\title{
Note on seismic hazard assessment using gradient of uplift velocities in the Turan block (Central Asia)
}

\author{
M. Jaboyedoff ${ }^{1,2}$, M.-H. Derron ${ }^{3}$, and G. M. Manby ${ }^{4}$ \\ ${ }^{1}$ Quanterra, CH-1007 Lausanne, Switzerland \\ ${ }^{2}$ Institute of Geomatics and Risk Analysis (IGAR), University of Lausanne, CH-1015 Lausanne, Switzerland \\ ${ }^{3}$ Geological Survey of Norway/International Center for Geohazards, 7491 Trondheim, Norway \\ ${ }^{4}$ Deartment of Earth and Environmental Sciences, University of Greenwich, Chatham Maritime, United Kingdom
}

Received: 26 July 2004 - Revised: 3 December 2004 - Accepted: 6 December 2004 - Published: 3 January 2005

Part of Special Issue "Precursory phenomena, seismic hazard evaluation and seismo-tectonic electromagnetic effects"

\begin{abstract}
Uplift gradients can provide the location of highly strained zones, which can be considered to be seismic. The Turan block (Central Asia) contains zones with high gradient of uplift velocities, above the threshold $0.04 \mathrm{~mm}$ $\mathrm{km}^{-1}$ year $^{-1}$. Some of these zones are associated with important seismic activity and others are not correlated with any recent important recorded earthquakes, however, recent faults scarps as well as diverted rivers may indicate a recent tectonic activity. This threshold of gradient is probably a significant rheologic property of the upper crust. On the basis of these considerations the Uzboy river area is proposed as a potential high seismic hazard zone.
\end{abstract}

\section{Introduction}

The Central Asian states of Turkmenistan and Uzbekistan lie on the Turan block and are frequently subjected to large magnitude earthquakes (Figs. 1 and 2). The Turan block is confined to the west by the Caspian Sea, to the east by the Tien Shan and Pamirs ranges. The E-W northern margin of this block pass along the southern side of the Aral Sea and the Ashgabat fault in the Kopet Dagh is the southern border of this block (Lyberis et al., 1998). Even if frequently presented as one coherent unit, the Turan block is actually a mosaic of microblocks accreted to Eurasia during the Late Paleozoic (Garzanti and Gaetani, 2002). From Late Permian to Eocene, subsidence and extension have dominated the area with the deposition of $2-17 \mathrm{~km}$ thick, post Triassic, sediments (Thomas et al., 1999b; Lyberis and Manby, 1999). Since the Oligocene, this basin has been subjected to compression due to the rapid Arabia-Turan oblique convergence in the south and the collision with the Indian plate in

Correspondence to: M. Jaboyedoff

(michel.jaboyedoff@quanterra.org) the southeast. Permo-Mezosoic faults have been reactivated and reversed during the Neogene (Lyberis and Manby, 1999). Without GPS data for the Kopet Dagh, the maximum rate of the Iran-Turan convergence is estimated to $16 \mathrm{~mm} / \mathrm{year}$ (Allen et al., 2004) using the plate velocities of Sella et al. (2002) and subtracting the deformation rate in the central Zagros. This rate is coherent with the mostly PlioceneQuaternary $75 \mathrm{~km}$ shortening of the Kopet Dagh described by Lyberis and Manby (1999). Descriptions of active tectonics around the Turan block have been published recently by Allen et al. (2003, 2004) and Jackson et al. (2004) for the South Caspian region, and by Walker et al. (2004) for the East Iran area. Only some particular neotectonic aspects of the inner part of the Turan block have been studied: 1) a sequence of three earthquakes at Gazli in Uzbekistan (Amorèse and Grasso, 1996; Bossu et al., 1996); 2) the propagation of the deformation (uplift velocity) from the Tien Shan and the Kopet Dagh to the Turan block (Thomas et al., 1999a); 3) the Quaternary evolution of the drainage system around the Aral Sea (Letolle and Mainguet, 1997) and in the Kopet Dagh (Trifonov, 1978).

New field and remote sensing investigations have revealed the presence of recent tectonic features in the Uzboy river area (western Turan block) without significant records of seismic events (Fig. 2). This area is considered as aseisimic by Thomas et al. (1999a) and as a low seismic hazard zone by methods based on historical records (Giardini et al., 1999) (Fig. 3). On the contrary, a new interpretation of the uplift velocities suggests that the Uzboy river area is a potential high seismic hazard zone. This interpretation is based on the observation that in the Swiss Alps most of the seismic active areas are located within areas with high gradient of uplift values (Jaboyedoff et al., 2003).

Interseismic uplift is often reported as the result of the deformation in locked zones (e.g. Hyndman and Wang, 1995). 


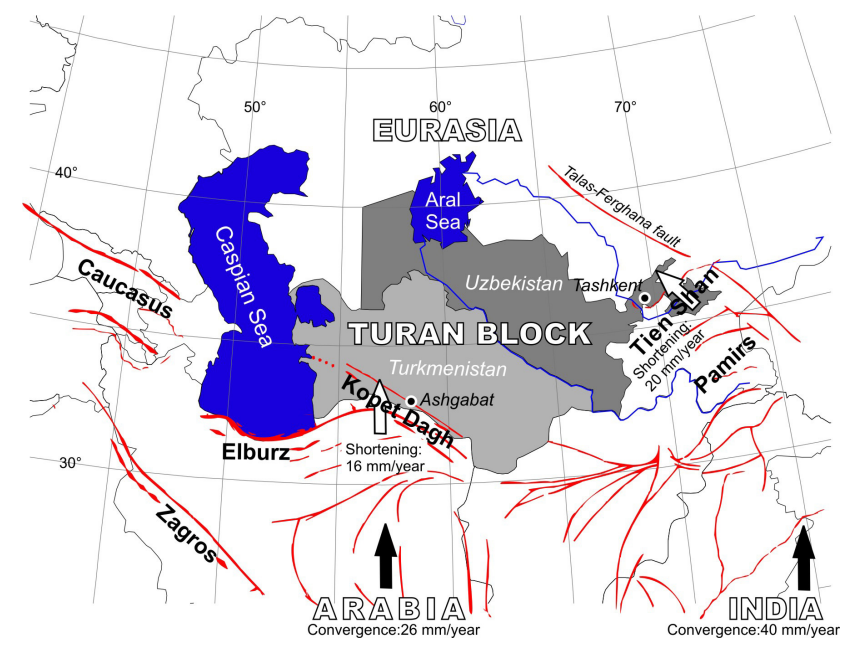

Fig. 1. Map of the Tuan block and adjacent areas. The main active areas (in red) are from Lyberis and Manby (1999). Convergence (relative to Eurasia) and shortening velocities are from Allen et al. (2004) and Abdrakhmatov et al. (1996).

The ruptures of these zones lead to coseismic uplift and subsidence (Keller and Pinter, 2002). Only limited uplift data coupled with earthquake data are available, for instance, the Cascadia subduction zone (British Columbia, Canada and California) indicates large gradient of uplifts velocities but no recent large earthquakes have been recorded. Nevertheless sediment analysis indicated that tsunamis and soil liquefaction occurred in the past centuries (Clague and Bobrowski, 1994; Atwater et al., 1991). From a geodynamic point of view, the Turan block presented some similarities with Cascadia subduction zone because the regional context is a shortening implying regional scale faults.

Despite the difference between the geodynamic settings of the Turan block, the Cascadia Subduction zones and Alpine areas, it is suggested here that the present day Turan Block is effectively in an interseismic period.

\section{Method}

The magnitude of the gradient vector norm of displacement velocities helps to define the highly strained areas. The horizontal displacement gradient near the fault of San Andreas indicates that the fault is located at the place of the highest value of the norm of the gradient (Shen et al., 1996). In the case of active reverse or normal locked faults, the strain leads to interseismic uplifts or subsidence by analogy with Hyndman and Wang (1995). Uplifts or subsidence movements can be coupled with strike-slip locked faults in local restraining bends (Spotila et al., 2003). It is assumed, therefore, that most of the interseismic uplift movements occur in the neighbourhood of the active locked faults (Fig. 4).

Areas of uplift and subsidence indicate movements and/or erosion in the vertical direction. High uplift gradients are usually associated with highly (vertical) strained areas. For a

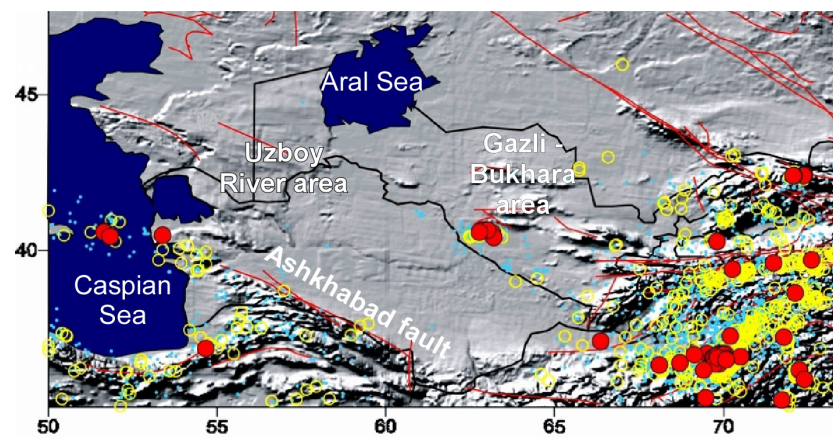

Fig. 2. Epicentres of the PDE database (1935-1998): the red circles correspond to Magnitude $>6.0$, the yellow circles: Magnitude $=5.0-$ 6.0, the blue dots: Magnitude=4.0-5.0.

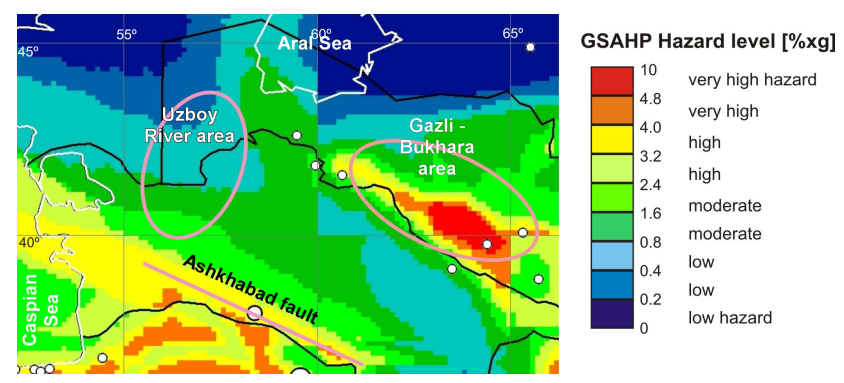

Fig. 3. GSAHP hazard level in the Turan block. Map extracted from the Global Seismic Hazard Map (modified after Giardini et al., 1999).

given gradient of a surface $f(x, y, z)=C$, where $x, y$ and $z$ are the spatial coordinates and $C$ a constant, the norm of the gradient is equal to the tangent of the slope of the surface. Assuming $v_{z}$ the uplift velocity, the gradient vector norm $(\boldsymbol{G})$ is given by Kreysig (1999) and Golden SW Inc. (1999):

$|\boldsymbol{G}|=\sqrt{\left(\frac{\partial v_{z}}{\partial x}\right)^{2}+\left(\frac{\partial v_{z}}{\partial y}\right)^{2}}$.

The computation of uplift gradients is performed using the natural neighbour method (Golden SW Inc., 1999). The gradient grid is obtained using the standard gradient operator of Golden SW Inc. (1999).

Regions where the potential vertical shear strains are the highest are given by the highest values of the uplift gradient. This implies that elastic rebounds, and fault slips adjust the upper brittle crust. In other words, areas showing differences in movements are the locations in which deformation is concentrated. Such areas are assumed to be prone to seismic activity, as Jaboyedoff et al. (2003) demonstrated in the Swiss Alps. The comparison of uplift gradient with historical earthquakes indicates that the areas with a gradient above $0.03 \mathrm{~mm} \mathrm{~km}^{-1}$ year $^{-1}$ are correlated with a high density of Swiss Alps historical earthquakes. 


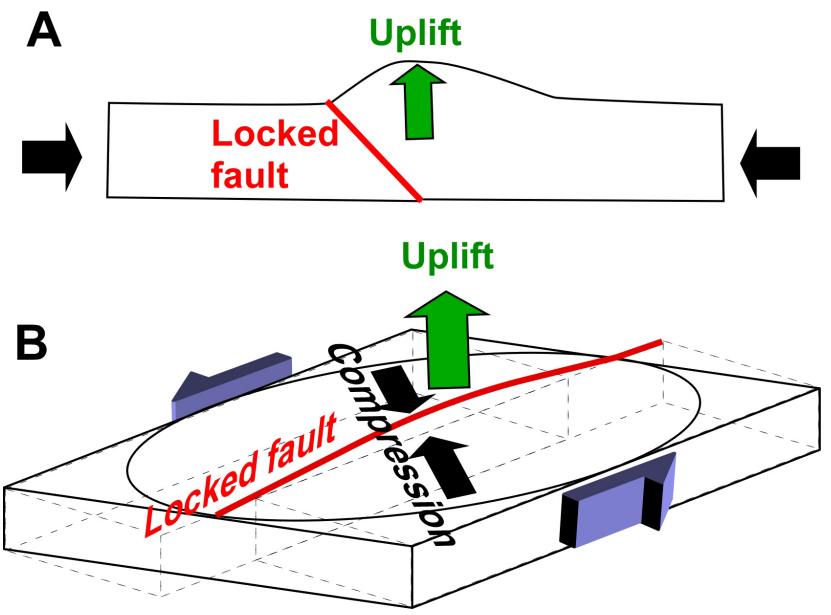

Fig. 4. (a) Example of possible geometry of locked reverse fault that leads to uplift (vertical scale is exagerated). (b) Situation of a locked strike-slip fault leading to an oblique uplift. The dashed lines indicate the relative movement of the two sides of anormally sliding faults.

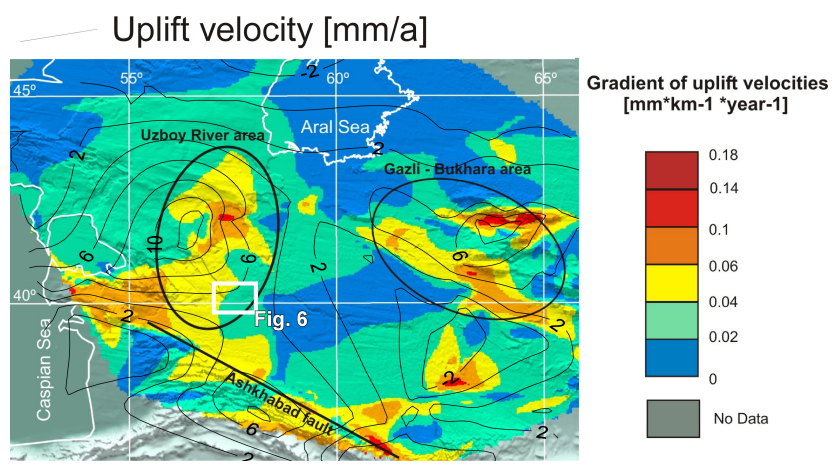

Fig. 5. Map of uplift velocities (contoured lines) and of gradient of uplift velocities on the Turan Block (data from Thomas et al., 1999a). The accuracy of the uplift data estimated by Thomas et al. (1999) is smaller than $1 \mathrm{~mm} /$ year for most of the points.

\section{Settings and issue}

The entire Turan block is subject to uplift with a mean velocity of $5 \mathrm{~mm} /$ year (Thomas et al., 1999a). This large-scale regional deformation, due to the collision of the Tien Shan and Arabia with the Eurasian plate, is accommodated by seismically active faults in the Kopet Dagh and in the northern part of the block (Gazli). Models of buckling of the lithosphere have been proposed to accommodate this compression in the Ferghana valley area, east of the Turan block (Burov and Molnar, 1998).

The southern boundary of the Turan plate coincides with the reverse-dextral Ashgabat fault, which was associated on 5 October 1948 with a 7.3 magnitude earthquake that destroyed Ashgabat, the capital city of Turkmenistan, killing 120000 people. The northern boundary of the Turan plate coincides with the latitude of the Buchara - Gazli cities (Uzbekistan) and it is also characterized with large earth-

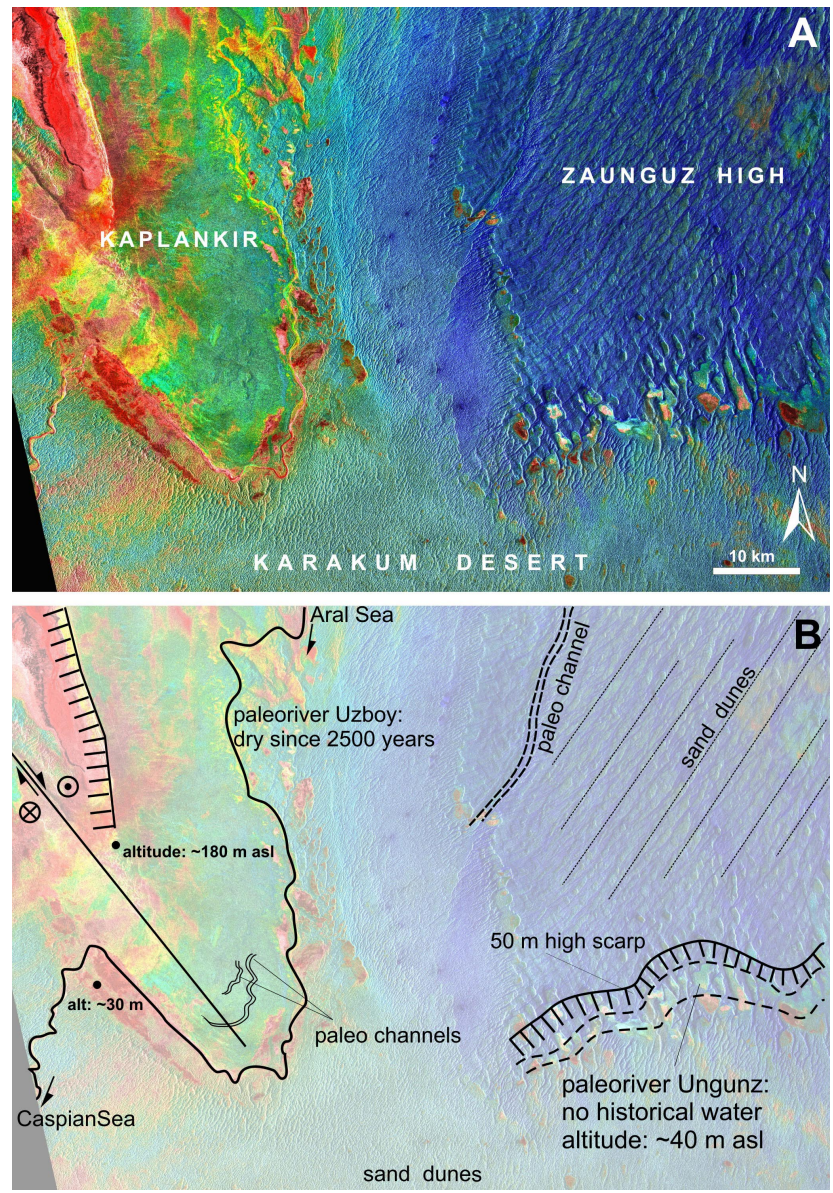

Fig. 6. Satellite image from the Uzboy River diverted by a fault. (a) image produced by a HIS-fusion of a Landsat image with a radar ERS image. The sand dunes are in blue (light and dark) and the bare rocks and other sediments in green/red/yellow. (b) simplified geological interpretation.

quakes that occurred in April and May 1976, with $M=7.0$ and $M=7.3$, respectively (Amorèse and Grasso, 1996; Thomas et al., 1999a). The capital of Uzbekistan, Tashkent, was also destroyed in 1968 by an earthquake of $\mathrm{M}=6.6$.

Leveling data from the Turan block (Thomas et al., 1999a) indicates high uplift velocities in three areas (Gazli-Buchara, Ashgabat and Uzboy) (Fig. 5). The CMT Harvard database provides focal mechanisms for the Ashgabat zone (strikeslip) and Gazli-Buchara area (thrust), but no earthquake was reported in the Uzboy area by either the CMT Harvard or the other avalaible databases since 1920 (Fig. 2) (PDE, ISC, SSR, Uzbek and Russian historical catalogues). Even if this catalogue of earthquakes can be considered as complete only for the last 30 years for the "low" magnitude events (45.5), the seismicity of the Uzboy area, described as aseismic (Thomas et al., 1999a), contrasts strongly with the two other rapidly uplifting regions. 


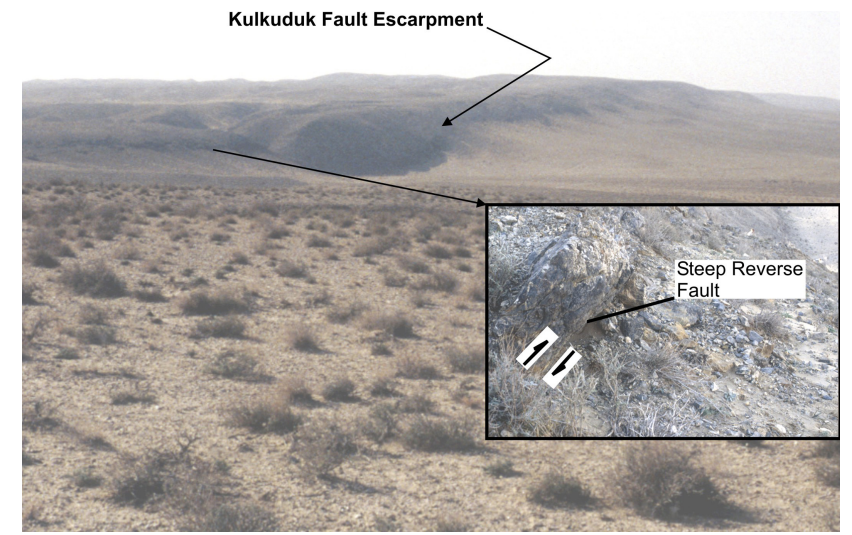

Fig. 7. The Kulkuduk fault is a reverse Quaternary fault in the NE part of the Uzboy area.

\section{Results}

4.1 High gradients of uplift velocities of the known seismic areas

Both highly hazardous areas (Gazli-Buchara and Ashgabat), after GSHAP (Giardini et al., 1999), have gradients of uplift greater than $0.04 \mathrm{~mm} \mathrm{~km}^{-1}$ year $^{-1}$ with a maximum of $0.16 \mathrm{~mm} \mathrm{~km}^{-1}$ year $^{-1}$ (Fig. 5). Assuming a gradient of $0.04 \mathrm{~mm} \mathrm{~km}^{-1}$ year $^{-1}$ during 1 million years between two points $100 \mathrm{~m}$ apart, the difference altitude between both points will be of $4 \mathrm{~m}$. With a gradient of $0.16 \mathrm{~mm} \mathrm{~km}^{-1}$ year $^{-1}$ in the same conditions the difference is of $16 \mathrm{~m}$. This implies high strained zones.

4.2 High gradient of uplift with no recent record of earthquake

In the area of the Uzboy River, without any historical record of major earthquake (since 1920), the gradient of uplift is above $0.03-0.04 \mathrm{~mm} \mathrm{~km}^{-1}$ year $^{-1}$. As shown previously such a value of gradient is usually linked to a significant seismic activity. Few data are published on the neotectonics of this area. Some small active faults are indicated in the "Map of active faults in Eurasia" for the Kara-Bogaz area (Trifonov, 1996) and Letolle and Mainguet (1997) have attributed the Quaternary modifications of the palaeo-drainage system Aral-Caspian to be the result of tectonic forcing in the area. Considering the N-S compression induced by the Arabia and the NW-SE compression from the Tien Shan, both reverse thrusting and strike-slip accommodation along faults can be expected, as it is the case in other parts of the Turan block (Thomas et al., 1999a). Fieldwork has revealed much evidence of recent tectonic movements, such as: faults, scarps, diverted rivers, uplifted terraces (Figs. 6 and 7). The occurrence of, high uplift gradients together with evidence of active tectonics, suggest that the Uzboy area is a region of high potential seismic hazard.

\section{Conclusions}

The construction of vertical gradient maps can potentially provide information on seismic hazard independently of a catalogue of seismic events. This method of vertical gradient does not suit to pure strike-slip movement, but most of the active structures possess a vertical movement component. Nevertheless, the method should be generalized in 3D with Insar and GPS data (Wright et al., 2001), because surveys by such method will be soon long enough to provide accurate data.

Both in Switzerland and on the Turan block, seismic areas are located in zones with gradient of uplift above 0.03$0.04 \mathrm{~mm} \mathrm{~km}^{-1}$ year $^{-1}$. Furthermore, the data of uplift in Cascadian subduction zone also indicate uplift gradients greater than $0.04 \mathrm{~mm} \mathrm{~km}^{-1}$ year $^{-1}$ (Hyndman and Wang, 1995). Because this limiting value is found in different geodynamic contexts, it may represent a rheological threshold property of the brittle upper crust, indicating that above this threshold the strain rate cannot be released plastically by the upper crust, inducing an elastic strain accumulation. This limit is certainly dependent on rock type, geothermal flux and crust thickness, but the magnitude order must be the same in most continental crust contexts (Sibson, 1983).

The recent tectonic is demonstrated by a rapid convergence which is expressed by faults occurrences, uplifts and present seismic activity in Gazli-Buchara and Ashgabat. The lack of recent seismic activity in the suspected highly strained Uzboy area suggests that a future earthquake may be of high magnitude.

Edited by: P. F. Biagi

Reviewed by: P. Burrato and another referee

\section{References}

Abdrakhmatov, K. Ye., Aldazhanov, S. A., Hager, B. H., Hamburger, M. W., Herring, T. A., Kalabaev, K. B., Makarov, V. I., Molnar, P., Panasyuk, S. V., Prilepin, M. T., Reilinger, R. E., Sadybakasov, I. S., Souter, B. J., Trapeznikov, Yu. A., Tsurkov, V. Ye., and Zubovich, A. V.: Relatively recent construction of the Tien Shan inferred from GPS measurements of present-day crustal deformation rates, Nature, 384, 450-453, 1996.

Allen, M. B., Vincent, S. J., Alsop, G. I., Ismail-Zadeh, A., and Flecker, R: Late Cenozoic deformation in the South Caspian region: effects of a rigid basement block within a collision zone, Tectonophysics, 366, 223-239, 2003.

Allen, M. B., Jackson, J., and Walker, R.: Late Cenozoic reorganization of the Arabia-Eurasia collision and the comparison of short-term and long-term deformation rates, Tectonics, 23, TC2008, doi:10.1029/2003TC001530, 2004.

Amorèse, D. and Grasso, J.-R.: Rupture planes of the Gazli earthquakes deduced from local stress tensor calculation and geodetic data inversion: Geotectonics implications, J. Geophys. Res., 101, B5, 11 263-11 274, 1996.

Atwater, B. F., Stuiver, M., and Yamaguchi, D. K.: Radiocarbon test of earthquake magnitude at the Cascadia subduction zone, Nature, 353, 156-158, 1991. 
Bossu, R., Grasso, J. R., Plotnikova, B., Nurtaev, J., Fréchet, J., and Moisy, M.: Complexity of intracontinental seismic faulting: the Gazli, Uzbekistan, sequence, Bull. Seismol. Soc. Am., 86, 959971, 1996.

Burov, E. B. and Molnar P.: Gravity anomalies over the Ferghana Valley (Central Asia) and intracontinental deformation, J. Geophys. Res., 103, B8, 18 137-18 152, 1998.

Clague, J. J. and Bobrowski, P. T.: Evidence for a large earthquake and tsunami 100-400 years ago on western Vancouver Island, British Columbia, Quaternary Res., 41, 176-184, 1994.

Garzanti, E. and Gaetani M.: Unroofing history of Late Paleozoic magmatic arcs within the "Turan Plate" (Tuarkyr, Turkmensitan), Sedim. Geol., 151, 67-87, 2002.

Giardini, D., Grünthal, G., Shedlock, K. M., and Zhang, P.: The GSHAP Global Seismic Hazard Map, Annali di Geofisica, 42, 1225-1230, 1999.

Hyndman, R. D. and Wang, K.: Constraints on the rupture zone of great earthquakes on the Cascadia subduction thrust from current deformation and thermal regime, J. Geophys. Res., 100, 22 13322 154, 1995.

Jaboyedoff, M., Baillifard, F., and Derron, M.-H.: Preliminary note on uplift rates gradient, seismic activity and possible implications for brittle tectonics and rockslide prone areas: The example of western Switzerland, Bull. Soc. Vaud. sc. nat., 88, 393-412, 2003.

Jackson, J., Priestley, K., Allen, M., and Berberian, M.: Active tectonics of the South Caspian Basin, Geophys. J. Int., 148, 214 245, 2004.

Keller, E. A. and Pinter, N.: Active tectonics, earthquakes, uplift, and landscape, Prentice Hall, 2002.

Kreysig, E.: Advanced engineering mathematics $8^{\text {th }}$ ed. Wiley \& Sons, 1056, 1999.

Letolle, R. and Mainguet, M.: Histoire de la Mer d'Aral (Asie Centrale) depuis le dernier maximum glaciaire, Bull. Soc. Geol. Fr., 168, 387-398, 1997.

Lyberis, N. and Manby, G.: Post-triassic evolution of the southern margin of the Turan plate, C. R. Acad. Sc., 326, 137-143, 1998.
Lyberis, N. and Manby, G.: Oblique to orthogonal convergence across the Turan Block in the post-Miocene, AAPG Bull., 83, 7, 1135-1160, 1999.

Sella, G. F., Dixon, T. H., and Mao, A.: REVEL: a model for recent plate velocities from space geodesy, J. Geophys. Res., 107, B4, 2081, doi:10.1029/2000JB00033, 2002.

Shen, Z. K., Jackson, D. D., and Ge, X. B: Crustal deformation across and beyond the Los Angeles basin from geodetic measurements, J. Geophys. Res., 101, 27 957-27 980, 1996.

Sisbson, R. H: Continental fault structure and shallow earthquakes source, J. Geol. Soc. London, 140, 741-767, 1983.

Spotila, J. A., House, M. A., Brady, R., Niemi, N. A., and Lukes, L.: Rock uplift along the San Andreas Fault and implications for processes of transpression, Geological Society of America Abstracts, 35/6, 304, 2003.

Golden SW Inc.: Surfer for Windows, user's guide V7, contouring and 3d surface mapping, Golden software Inc. Colorado, 400, 1999.

Thomas, J.-Ch., Grasso, J. R., Bossu, R., Martinod, J., and Nurtaev, B.: Recent deformation on Turan and south Kazakh platforms, western central Asia, and its relation to Arabia-Asia and IndiaAsia collisions, Tectonics, 18, 201-214, 1999a.

Thomas, J.-Ch., Cobbold, P. R., Shein, V. S., and Le Douaran, S.: Sedimentary record of Late Paleozoic to recent tectonism in Central Asia - analysis of subsurface data from the Turan and south Kazak domains, Tectonophysics, 313, 243-263, 1999 b.

Trifonov, V. G.: World map of active faults in Eurasia: principles, methods and results, J. Earthquakes Prediction Res., 5, 326-347, 1996.

Trifonov, V. G.: Late Quaternary Tectonic Movement of Western and Central Asia, Bull. Soc. Geol. Am., 89, 1059-1072, 1978.

Walker, R., Jackson, J., and Baker, C.: Active faulting and seismicity of the Dasht-e-Bayaz region, eastern Iran, Geophys. J. Int., 157, 265-282, 2004.

Wright, T., Parsons, B., and Fielding, E.: Measurement of interseismic strain accumulation across the North Anatolian Fault by satellite radar interferometry, Geophys. Res. Lett., 28, 10, 21172120, 2001. 